\title{
РОБОТА ЦИВІЛЬНИХ ЗАКЛАДІВ ОХОРОНИ ЗДОРОВ'Я З НАДАННЯ МЕДИЧНОЇ ДОПОМОГИ ВІЙСЬКОВОСЛУЖБОВЦЯМ ПІД ЧАС АТО/ООС, А ТАКОЖ ДЕМОБІЛІЗОВАНИМ УЧАСНИКАМ АТО ТА ВНУТРІШНЬО ПЕРЕМІЩЕНИМ 3 ТИМЧАСОВО ОКУПОВАНИХ ТЕРИТОРІЙ ОСОБАМ
}

\author{
В.Г. Лівінський
}

Українська військово-медична академія, м. Київ

\begin{abstract}
Вступ. Дослідження роботи цивільних 303 з надання медичної допомоги пораненим військовослужбовцям та іншим категоріям громадян під час антитерористичної операції та операції Об'єднаних сил (ATO/OOC), а також вивчення їх спроможностей з метою використання в особливий період в інтересах ЗС України та інших військових формувань є актуальним.

Мета роботи - аналіз та узагальнення досвіду роботи цивільних закладів охорони здоров'я з надання медичної допомоги пораненим, травмованим $i$ хворим військовослужбовиям під час антитерористичної операції та операції Об'єднаних сил (АТО/OOC), а також демобілізованим учасникам АТО та внутрішньо переміщеним особам з окупованих територій АР Крим, Донецької та Луганської областей.

Матеріали та методи. Використані нормативно-правові акти з питань оборони держави та охорони здоров'я, керівні документи, інформаційно-довідкові видання з питань охорони здоров'я населення та медичного забезпечення Збройних Сил (ЗС) Украӥни. Методи дослідження: історичний, бібліографічний, системного підходу, статистичний, аналітичний, узагальнення.

Результати. У статті розглянуто історичний та закордонний досвід використання цивільних закладів охорони здоров'я для надання медичної допомоги військовослужбовиям під час воєн та збройних конфліктів, досліджено нормативно-правові засади залучення їх до системи лікувально-евакуаційних заходів медичного забезпечення ЗС України. Проаналізовано роботу цивільних закладів охорони здоров'я та клінічних установ Національної академії медичних наук України з надання медичної допомоги пораненим, травмованим $і$ хворим військовослужбовиям, демобілізованим учасникам АТО та внутрішньо переміщеним з тимчасово окупованих територій особам, а також встановлено чинники, що впливали на їх роботу.

Висновки. У районах проведення АТО/ООС на засадах єдиного медичного простору сформувалася територіальна система надання медичної допомоги пораненим, травмованим $i$ хворим військовослужбовиям, яка функціонально об'єднала медичні підрозділи військових частин і з'єднань, військово-медичні заклади, а також цивільні заклади охорони здоров'я. За досвідом медичного забезпечення військ під час проведення АТО/OОС опрацьовано механізм і порядок залучення системи цивільної охорони здоров'я до надання медичної допомоги військовослужбовиям під час воєн та збройних конфліктів.
\end{abstract}

Ключові слова: охорона здоров'я, медична допомога, медичне забезпечення.

Вступ. Медичне забезпечення $є$ окремим видом забезпечення Збройних Сил (3С) України і являє собою систему заходів щодо збереження та зміцнення здоров'я особового складу, запобігання виникненню та розповсюдженню хвороб, надання медичної допомоги військовослужбовцям, їх лікування і відновлення працездатності та боєздатності після поранень, захворювань і травм [1]. Для реалізації завдань щодо медичного забезпечення у складі військових частин і з'єднань сформовано медичні підрозділи, а також визначену кількість мобільних та стаціонарних військово-медичних закладів мають Медичні сили Збройних Сил України. Під час збройних конфліктів вони забезпечують потреби військ 3 надання медичної допомоги пораненим, ураженим, травмованим і хворим безпосередньо на полі бою та в районах бойових дій, проте для надання повного спектру спеціалізованої та високоспеціалізованої медичної допомоги військовослужбовцям, лікування до повного одужання та медичної реабілітації їх недостатньо.

Історичний та закордонний досвід свідчить про необхідність залучення цивільних закладів охорони здоров'я (303) для надання медичної допомоги військовослужбовцям під час воєн та збройних конфліктів. Так, у збройних силах США, Німеччини, Великобританії, Франції, Норвегії, Угорщини, Польщі, Литви, Латвії, Естонії та інших країн передбачається використання національних цивільних 303 на четвертому рівні медичного забезпечення $[2,3,4,5,6,7]$. Особливої уваги заслуговує досвід організації медичного забезпечення збройних сил Ізраїлю, 
які не мають власних військових госпіталів, проте кожна цивільна лікарня країни під час кризових ситуацій спроможна швидко трансформуватися у військовий госпіталь [8].

Зважаючи на зазначене дослідження роботи цивільних 303 з надання медичної допомоги пораненим військовослужбовцям та іншим категоріям громадян під час антитерористичної операції та операції Об’єднаних сил (АТО/ООС), а також вивчення їх спроможностей з метою використання в особливий період в інтересах ЗС України та інших військових формувань є актуальним.

Мета роботи. Аналіз та узагальнення досвіду роботи цивільних 303 з надання медичної допомоги пораненим, травмованим i хворим військовослужбовцям, демобілізованим учасникам АТО/OОС, а також внутрішньо переміщеним особам з тимчасово окупованих територій Автономної Республіки (АР) Крим, Донецької та Луганської областей.

Об'єкт дослідження - цивільні 303. Предмет дослідження - робота цивільних 3033 надання медичної допомоги пораненим, травмованим і хворим військовослужбовцям, демобілізованим учасникам ATO/OOC, а також внутрішньо переміщеним особам з тимчасово окупованих територій АР Крим, Донецької та Луганської областей.

Матеріали та методи дослідження. Використані нормативно-правові акти з питань оборони держави та охорони здоров'я, керівні документи, інформаційно-довідкові видання 3 питань охорони здоров'я в державі та медичного забезпечення ЗС України. Методи дослідження: історичний, бібліографічний, системного підходу, статистичний, аналітичний, узагальнення.

Результати дослідження та їх обговорення. 3 самого початку АТО на Сході України цивільні 303, насамперед ті, що розташовані у Донецькій і Луганській областях, а також у суміжних з ними Харківській, Дніпропетровській та Запорізькій областях, крім надання медичної допомоги цивільному населенню, активно включилися у надання медичної допомоги пораненим, ураженим, травмованим і хворим військовослужбовцям ЗС України та інших військових формувань.

Прикладом узгодженості в роботі та успішного вирішення питань надання медичної допомоги військовослужбовцям ЗС України та інших військових формувань, співробітникам правоохоронних органів - учасникам АТО та членів їхніх сімей, а також цивільному населенню стала Харківська область, де ці питання були визнані одними з пріоритетних у діяльності місцевих органів влади. Розпорядженням голови Харківської обласної державної адміністрації (ОДА) від 08.10.2015 року № 483 в області створено обласний центр допомоги учасникам АТО, який став центром взаємодії 3 органами виконавчої влади, місцевого самоврядування, установами та організаціями [9].

Протягом 2015-2016 років реанімаційними бригадами комунального закладу охорони здоров'я (КЗОЗ) «Центр екстреної медичної допомоги та медицини катастроф» здійснено 350 виїздів бригад екстреної медичної допомоги 3 метою продовження «естафетного» транспортування поранених і травмованих військовослужбовців, а також потерпілих жителів Донецької та Луганської областей до закладів охорони здоров'я м. Харкова (у 2015 р. 239 транспортувань, у 2016 р - 111). Крім того, бригадами екстреної медичної допомоги в області надано медичні послуги 9445 осібам з числа вимушених переселенців (у 2015 р. 5844 особи, у 2016 p - 3601 осіб) [9, 10].

Відповідно до реєстру, що ведеться в Управлінні охорони здоров'я Харківської ОДА, з початку проведення АТО до комунальних 303 звернулося за медичною допомогою 120620 осіб 3 числа тимчасово переміщених з АР Крим, Донецької та Луганської областей до Харківської області (у тому числі 81989 дорослих та 38631 дітей). Стаціонарна допомога надана 32661 особі або 27,1 \% від загальної кількості зареєстрованих, у тому числі 20949 дорослим та 11712 дітям (з них 1468 новонародженим). Амбулаторну медичну допомогу отримали 87959 осіб (72,9\% від загальної кількості зареєстрованих), у тому числі 61040 дорослих та 26919 дітей $[9,10,11]$.

На підставі сформованих за даними Харківського обласного військового комісаріату списків демобілізованих осіб на базі КЗОЗ «Обласний госпіталь ветеранів війни» було створено реєстр демобілізованих військовослужбовців та членів їхніх родин. Протягом 2016 року оглянуто 5043 особи або 75,7 \% від усіх демобілізованих, які зареєстровані в закладах охорони 
здоров'я, вперше виявлено 1608 випадків патології (32\% від числа оглянутих). На диспансерний облік взято 2731 особу, або 54,2\% від оглянутих. Підлягало стаціонарному лікуванню 580 осіб, проведено стаціонарне лікування 458 особам або 79,0\%. Потребу в амбулаторному лікуванні встановлено у 1268 осіб. Станом на 01.01.2017 року проліковано амбулаторно 965 осіб або $76,1 \%$ від тих, що його потребували. Потребували зубного протезування 1033 особи, запротезовано 310 осіб.

На медичний облік взято 9563 членів сімей демобілізованих учасників АТО, в тому числі батьків демобілізованих - 3029 осіб, дітей - 3638 осіб, дружин (чоловіків) - 2462 особи, інші 434 особи.

3 травня 2014 року 303 Дніпропетровської області не припиняють прийом поранених, травмованих і хворих військовослужбовців, цивільних осіб - учасників АТО/ООС, а також тимчасово переміщених громадян зі східних областей України та АР Крим. Для медичної евакуації поранених із зони АТО в області задіяні 213 бригад швидкої медичної допомоги та екстреної медичної допомоги [9].

Протягом 2015 року в 303 області надано допомогу 6927 особам із числа поранених, травмованих і хворих військовослужбовців ЗС України та інших військових формувань, а також осіб із добровольчих батальйонів та просто постраждалих громадян, із них прооперовано 2089 осіб. За результатами лікування комісією медико-соціальної експертизи було оглянуто 885 учасників АТО, із них визнано інвалідами 349 осіб.

Станом на кінець 2018 року центрами первинної медико-санітарної допомоги оглянуто 76827 осіб із числа військовослужбовців та інших учасників АТО/ООС, а також членів їхніх сімей, у тому числі проведено профілактичних оглядів із залученням лабораторних та інструментальних методів обстеження та консультацій фахівців - 76624 особам. Взято на диспансерний облік 22462 особи, амбулаторно проліковано - 17005 осіб, госпіталізовано та проліковано - 6928 осіб, у тому числі 2104 дитини [11].

Медична допомога в лікувально-профілактичних закладах області надана 10208 пораненим, травмованим і хворим військовослужбовцям, цивільним особам - учасникам АТО/OОС, з них за 2018 рік надано медичну допомогу 913 особам. Найбільшу кількість учасників АТО/ООС прийняв КЗОЗ «Дніпропетровська обласна клінічна лікарня імені I.I. Мечникова» - 2466 поранених з початку АТО, у тому числі в 2018 році - 109 осіб. Пораненим виконано 3560 хірургічних втручань, у тому числі у 2018 році - 134. За цей час виконано понад 200 оперативних втручань вищого рівня складності при вогнепальних пораненнях головного та спинного мозку, у відділенні мікрохірургії вуха відновлено слух після акустичних вибухових травм понад 120 пораненим [11].

Надання психотерапевтичної і психологічної допомоги та проведення медичної реабілітації здійснюється у 10 лікувально-профілактичних закладах області, за 2018 рік отримали таку допомогу 2354 учасники ATO/OOC, 3 них стаціонарно - 2154 особи, амбулаторно - 200 осіб [11].

3 грудня 2015 року на базі Дніпропетровського обласного госпіталю ветеранів війни функціонує центр реабілітації учасників АТО, де проводиться медикаментозне лікування, а також фізична, психологічна, психотерапевтична та психіатрична реабілітація. Протягом 20152018 років отримали лікування 2660 учасників АТО/OОС, 3 них у 2018 році 892 особи $[9,10,11]$.

у 2018 році на диспансерному обліку в лікувально-профілактичних закладах Дніпропетровської області перебувало 11832 учасника АТО/ООС, із них комісією медикосоціальної експертизи оглянуто 2028 осіб, визнано інвалідами 987 осіб, 896 особам встановлені відсотки втрати працездатності від 25 \% до 50 \% [11].

У Запорізькій області відповідним наказом Департаменту охорони здоров'я ОДА визначені 303 для надання медичної допомоги особам, постраждалим під час АТО, а саме: КЗО3 «Запорізька обласна клінічна лікарня», КЗОЗ «Обласна психіатрична лікарня», КЗОЗ «Запорізький обласний госпіталь для ветеранів війни» та КЗОЗ «Санаторій медичної реабілітації «Глорія». Психіатрична реабілітація демобілізованих осіб здійснюється закладами Спеціалізованого територіального медичного об’єднання «Психіатрія» у повному обсязі за 
бюджетні кошти в межах бюджетного фінансування. 3 метою своєчасного обліку демобілізованих військовослужбовців-учасників АТО/OOC та забезпечення наступності в організації проведення реабілітаційних заходів у зазначених закладах охорони здоров'я налагоджена співпраця з в військовими комісаріатами [9].

У 2014 році, зокрема під час загострення бойових дій, судинні хірурги КЗО3 «Запорізька обласна клінічна лікарня» неодноразово брали участь у наданні медичної допомоги пораненим військовослужбовцям ЗС України та Національної гвардії України на базі Маріупольської лікарні швидкої медичної допомоги.

У 2015 році у закладах охорони здоров'я області перебувало під диспансерним наглядом 2146 учасників АТО, отримали стаціонарне лікування 192 особи, санаторно-курортне лікування - 155 осіб [9].

За даними військових комісаріатів, станом на кінець 2016 року в області знаходилося понад 5400 демобілізованих учасників АТО. Протягом 2016 року до закладів охорони здоров'я області звернулося за медичною допомогою 5098 колишніх військовослужбовців, із них госпіталізовано 2381 особу. Медична допомога надана 4453 демобілізованим учасникам АТО (у т.ч. 1335 особам з приводу захворювань та 3118 осіб пройшли профілактичні медичні огляди). До медико-соціальних експертних комісій звернулося 162 колишніх військовослужбовця, з них 101 встановлено групи інвалідності [10].

Протягом 2016 року надана медична допомога 25446 внутрішньо переміщеним особам, які прибули на територію області з тимчасово окупованих територій Донецької і Луганської областей та АР Крим, з них 11268 дітям. Взято на облік 1485 осіб, 3 них 320 дітей. Госпіталізовано 7824 особи, з них 3348 дітей, проведено оглядів - 7305 [10].

У Донецькій області (на території підконтрольній Україні) на обліку в органах соціального захисту населення перебуває 12663 учасника АТО/ООС в т.ч.12 405 осіб зі статусом учасника бойових дій, 118 осіб з інвалідністю внаслідок війни та 140 учасників війни [11].

В області реалізовується Регіональна програма щодо медичного та соціального забезпечення, адаптації, психологічної реабілітації, професійної підготовки (перепідготовки) учасників антитерористичної операції, яка затверджена розпорядженням голови ОДА керівника обласної військово-цивільної адміністрації від 07.04.2016 р. № 266.

Згідно наказу Департаменту охорони здоров’я від 07.06.2016 p. № 350 «Про забезпечення медико-психологічної допомоги та реабілітації учасників АТО та прирівняних до них осіб» у лікувальних закладах визначені відповідальні особи за координацію роботи по наданню медичної допомоги демобілізованим учасникам АТО, створено резерв ліжок для безвідмовної госпіталізації даної категорії, а також затверджена «Дорожня карта демобілізованого військовослужбовця», яка служить своєрідним орієнтиром і дороговказом для медичних працівників [10].

Всього під диспансерним наглядом перебуває 1099 демобілізованих учасників АТО/ООС. Протягом 2017-2018 років звернулося за медичною допомогою до лікувальних установ за місцем проживання 2963 особи (24\% від перебуваючих на обліку). Амбулаторне лікування за пільговими рецептами отримали 660 демобілізованих учасників АТО/ООС (22\% від осіб, які звернулися за допомогою) на суму 408 тис. грн. В стаціонарах лікувальних закладів проліковано 471 особу із означеної категорії, загалом ними проведено 5767 ліжко-днів. У медико-соціальних експертних комісіях оглянуто 199 осіб з питань встановлення групи інвалідності та частки втрати працездатності. Вперше визнано інвалідами 118 осіб, у т. ч. I групи - 1 особа, II групи - 26 осіб, III групи - 91 особа. Усім інвалідам надані рекомендації 3 медичної, психологічної, професійної та соціальної реабілітації [11].

Реабілітація учасників АТО/ООС з розладами психіки та поведінки здійснюється в КЗОЗ «Обласна психіатрична лікарня» (м. Слов'янськ), де для цієї категорії пацієнтів розгорнуто 60 госпітальних ліжок. За 2018 рік у ньому пройшли стаціонарне лікування 126 військовослужбовців, якими проведено загалом 2294 ліжко-дні.

До надання медичної допомоги військовослужбовцям ЗС України та інших військових формувань на території Луганської області задіяні КЗОЗ «Попаснянська центральна районна лікарня», Станично-Луганське районне територіальне медичне об'єднання та КЗО3 «Щастинська міська лікарня Новоайдарського району Луганської області». У зазначених 303 
працюють військові лікарсько-сестринські бригади, які надають медичну допомогу військовослужбовцям та цивільному населенню. Протягом 2018 року у цих 303 надано медичну допомогу 299 військовослужбовцям, яким проведені необхідні оперативні втручання, первинну хірургічну обробку ран тощо. Після надання медичної допомоги військовослужбовці санітарним транспортом евакуюються на наступні етапи медичної евакуації [9].

Згідно розпорядження голови Луганської ОДА від 27.03.2017 p. № 185 у м. Рубіжне відкрито Центр відновлювального лікування та реабілітації ветеранів війни потужністю 30 ліжок, де протягом року отримали медичну допомогу 330 осіб, у тому числі: учасники бойових дій - 99; інваліди війни - 30; діти війни - 26; інваліди із числа колишніх військовослужбовців - 1; учасники АТО/OОC - 67; члени сімей учасників АТО/OOC - 34 та інші категорії населення [11]. У м. Гірське Попаснянського району (на відстані 7 км від лінії зіткнення) на базі підрозділу КЗОЗ «Попаснянська центральна районна лікарня» організовано операційний блок, в якому бригада військових медиків надає хірургічну допомогу пораненим та іншим постраждалим.

Протягом 2018 та 2019 років цивільні 303 під керівництвом департаментів та управлінь охорони здоров'я ОДА продовжували роботу щодо надання медичної допомоги пораненим, травмованим і хворим військовослужбовцям, демобілізованим учасникам АТО/ООС, а також внутрішньо переміщеним особам з тимчасово окупованих територій АР Крим, Донецької та Луганської областей. До проведення цієї роботи залучені обласні госпіталі ветеранів війни, на базі яких функціонують центри реабілітації учасників АTO/OOC, де проводиться медикаментозне лікування, фізична, психологічна, психотерапевтична та психіатрична реабілітація. В ряді санаторно-курортних закладів відкрито відділення медичної реабілітації учасників бойових дій.

Національна академія медичних наук (НАMН) України також не залишалася осторонь проблем надання медичної допомоги, зокрема високотехнологічної високоспеціалізованої, пораненим, ураженим, травмованим і хворим військовослужбовцям-учасникам АТО/ООС i постраждалому цивільному населенню. У клінічних установах НАМН України розгорнуто 550 спеціалізованих ліжок для лікування та реабілітації учасників АTO/OOC, а станом на 12.08.2019 р. в них проконсультовано та проліковано близько 15,7 тисяч найбільш тяжких поранених, травмованих і хворих військовослужбовців та близько 100 тисяч пацієнтів 3 Донецької та Луганської областей [12].

На роботу цивільних закладів охорони здоров'я, розташованих на адміністративних територіях Донецької та Луганської областей, де проводиться АТО/О0С, а також суміжних 3 ними областей, впливали такі чинники:

розбалансування мережі закладів охорони здоров’я, втрата матеріально-технічних засобів (медичного обладнання, апаратури, санітарного транспорту), руйнування будівель тощо;

низька укомплектованість цивільних закладів охорони здоров'я лікарями та іншим медичним персоналом через від'їзд останніх з адміністративних територій, де проводиться ATO/OOC;

залучення персоналу цивільних закладів охорони здоров'я для надання медичної допомоги пораненим, травмованим і хворим військовослужбовцям;

збільшення навантаження на цивільні заклади охорони здоров'я, що розташовані в Харківській, Дніпропетровській та Запорізькій областях, за рахунок прибуття внутрішньо переміщених осіб з тимчасово окупованих територій АР Крим, Донецької та Луганської областей;

наявність великої кількості демобілізованих військовослужбовців-учасників АTO/OOC із числа мешканців Харківської, Дніпропетровської та Запорізької областей, які потребують проведення додаткових лікувально-діагностичних та експертних заходів, а також медичної, психологічної та медико-соціальної реабілітації.

Під час збройного конфлікту на Сході України проявилися проблеми у вітчизняній системі охорони здоров'я, що накопичувалися роками, але на них практично ніхто не звертав увагу, вважаючи їх другорядними. Насамперед - це відсутність взаємодії між військово- 
медичними службами ЗС України та інших військових формувань, а також системою цивільної охорони здоров'я та, як результат, відсутність спадкоємності у наданні медичної допомоги пораненим, травмованим і хворим військовослужбовцям як у районах бойових дій, так і на наступних етапах медичної евакуації, що негативно відображалося на результатах їх лікування. Положення урядової постанови [13], якою передбачалося створення загальнодержавної системи екстремальної медицини на випадок екстремальних ситуацій, надзвичайного стану і на воєнний час, так і не були реалізовані.

3 метою вирішення зазначених проблем керівництвом медичної служби ЗС України було вжито ряд невідкладних заходів. Насамперед за домовленістю керівників військовомедичних служб з керівниками підрозділів 3 питань охорони здоров'я обласних державних адміністрацій було узгоджено питання надання медичної допомоги пораненим військовослужбовцям у цивільних закладах охорони здоров'я в районах проведення АТО.

У подальшому наказом Міністерства охорони здоров'я України доручалося керівникам структурних підрозділів з питань охорони здоров'я обласних та Київської міської державних адміністрацій забезпечити роботу закладів охорони здоров'я у режимі підвищеної готовності, створивши резерв профільних ліжок у закладах охорони здоров'я (не менше 30\%) для надання невідкладної медичної допомоги постраждалим [14]. Водночас зазначений наказ не вирішував усіх проблемних питань надання медичної допомоги та лікування поранених, уражених, травмованих і хворих військовослужбовців.

3 урахуванням досвіду медичного забезпечення військ і цивільного населення в районах проведення АТО/ООС та суміжних 3 ними областях фахівцями Військово-медичного департаменту Міністерства оборони України (ВМД МОУкраїни) та Української військовомедичної академії (УВМА) опрацьовано розпорядження Кабінету Міністрів України «Деякі питання медичного забезпечення військовослужбовців, осіб рядового і начальницького складу та поліцейських, які беруть участь в антитерористичній операції та здійсненні заходів із забезпечення національної безпеки і оборони, відсічі і стримування збройної агресії Російської Федерації у Донецькій та Луганській областях» (Розпорядження) [15].

На виконання цього Розпорядження та з метою встановлення механізму надання військовослужбовцям вторинної (спеціалізованої) i третинної (високоспеціалізованої) медичної допомоги та підготовки визначених цивільних закладів охорони здоров'я до роботи на випадок ескалації збройного конфлікту на Сході України у ВМД МО України за участі фахівців УВМА опрацьовано наказ Міністерства оборони України та Міністерства охорони здоров'я України «Про визначення механізму надання вторинної (спеціалізованої) і третинної (високоспеціалізованої) медичної допомоги військовослужбовцям, які беруть участь в антитерористичній операції та здійсненні заходів із забезпечення національної безпеки i оборони, відсічі і стримування збройної агресії Російської Федерації та/або в умовах запровадження воєнного чи надзвичайного стану» (Наказ), який зареєстрований у Міністерстві юстиції України [16].

Цим Наказом затверджено Інструкцію щодо організації та порядку надання вторинної (спеціалізованої) і третинної (високоспеціалізованої) медичної допомоги військовослужбовцям ЗС України, інших військових формувань та правоохоронних органів, особам рядового i начальницького складу та поліцейським, які беруть участь в антитерористичній операції, та Перелік закладів охорони здоров'я з визначеною кількістю спеціалізованих ліжок, що для цього залучаються. До Переліку включено 253 заклади охорони здоров'я комунальної власності в 22 областях України, в яких майже 20 тисяч профільних ліжок виділяються для надання вторинної (спеціалізованої) і третинної (високоспеціалізованої) медичної допомоги та лікування поранених, уражених, травмованих і хворих військовослужбовців. Ще 1000 ліжок виділяється для зазначених цілей у 27 клінічних установах НАМН України. Детально законодавчі та нормативно-правові засади, а також організаційні та практичні питання щодо порядку залучення цивільних закладів охорони здоров'я в інтересах медичного забезпечення військ під час особливого періоду або в умовах запровадження воєнного чи надзвичайного стану висвітлені в монографії «Єдиний медичний простір та військова медицина» та «Методичних рекомендаціях з організації роботи цивільних закладів охорони здоров'я щодо 
надання вторинної (спеціалізованої) та третинної (високоспеціалізованої) медичної допомоги військовослужбовцям Збройних Сил України та інших військових формувань» $[17,18]$.

\section{Висновки}

1.У досліджені проаналізовано роботу цивільних 303 з надання медичної допомоги пораненим військовослужбовцям та іншим категоріям громадян під час АТО/ООС, встановлено чинники, що впливають на їх роботу, а також вивчено можливість використання в особливий період спроможностей цивільних 303 в інтересах медичного забезпечення ЗС України та інших військових формувань.

2.Встановлено, що в районах проведення АTO/OOC на засадах єдиного медичного простору сформувалася територіальна система надання медичної допомоги пораненим, травмованим і хворим військовослужбовцям, яка функціонально об'єднала медичні підрозділи військових частин і з'єднань, військово-медичні заклади, а також цивільні 303.

3. Основними чинниками, що ускладнюють роботу цивільних 303 Донецької та Луганської областей, де проводиться АТО/ООС, а також суміжних 3 ними Харківської, Дніпропетровської та Запорізької областей, є проблеми матеріально-технічного забезпечення, кадровий дефіцит та зростання навантаження на медичних фахівців за рахунок збільшення чисельності контингенту, який обслуговується.

4. 3 урахуванням набутого досвіду медичного забезпечення військ під час ATO/OOC у Мо України розроблено та затверджено державними нормативними актами механізм і порядок залучення системи цивільної охорони здоров'я до надання в особливий період спеціалізованої та високоспеціалізованої медичної допомоги пораненим, ураженим, травмованим і хворим військовослужбовцям ЗС України та інших військових формувань.

\section{Література}

1. Про затвердження Доктрини медичного забезпечення Збройних Сил України // Наказ Генерального штабу Збройних Сил України № 445 від 20.12.2017 року.

2. Медико-санітарна служба Бундесверу / Інформаційний огляд № 4(38). - Київ: 2009. - 54 с.

3. Організація медичного забезпечення збройних сил європейських держав: навч. посіб. 3 курсу інозем. мед. термінології / М.І. Бадюк, О.В. Рудинський та ін. - К. : СПД Чалчинська Н.В., 2014. - 104 с.

4. Голота А.С. "Медицинская служба вооруженных сил Норвегии” / Журнал "Военно-медицинский журнал”. - № 9’2014. - С. 68-73.

5. Голота А.С. "Медицинская служба вооруженных сил Литвы” / Журнал "Военно-медицинский журнал". - № 1'2016. - С. 49-53.

6. Алейников С.В. “Медицинская служба национальных вооруженных сил Латвии” / Журнал “Военно-медицинский журнал”. - № 8'2015. - С. 58-62.

7. Анисимов А.С. "Медицинская служба сил обороны Эстонии” / Журнал “Военно-медицинский журнал" - № 6'2015. - С. 61-64.

8.Ізраїльський лікар розповів про досвід військової медицини Ізраїлю - [Електронний ресурс], - Режим доступу: http://galinfo.com.ua/news/izrailskyy likar rozpoviv pro dosvid viyskovoi medytsyny izrailyu 189706.html. Заголовок з екрана. Знято 01.04.2015 p.

9. Мельник П.С. Характеристика медичного забезпечення антитерористичної операції / П.С. Мельник, М.В. Кудренко, Н.А. Козінчук, А.В. Верба, В.О. Жаховський, В.Г. Лівінський, О.В. Галацан, В.П. Філіпішин, О.В. Дроботун, Н.Ю. Будяк, М.П. Клименко, В.І. Клименко // “Щорічна доповідь про стан здоров'я населення, санітарно-епідемічну ситуацію та результати діяльності системи охорони здоров'я України. 2015 рік” / За ред. Шафранського В.В.; МОЗ України, ДУ “УІСД МОЗ України”. - Київ, 2016. - 452 с.

10. Мельник П.С. Характеристика медичного забезпечення в зоні антитерористичної операції / П.С. Мельник, М.В. Кудренко, Г.О. Слабкий, О.О. Коваленко, А.В. Верба, В.О. Жаховський, В.Г. Лівінський, В.І. Коробка, Л.М. Шугалей, В.Г. Волоха, Г.М. Сіроштан, В.І. Клименко, В.В. Колесник, В.В. Кулик, Ю.В. Інкелевич // “Щорічна доповідь про стан здоров'я населення, санітарно-епідемічну ситуацію та результати діяльності системи охорони здоров'я України. 2016 рік” / МОЗ України, ДУ “УІСД МО3 України". - Київ, 2017. - С. 384-432.

11. Мельник П.С. Характеристика медичного забезпечення в зоні антитерористичної операції / П.С. Мельник, М.В. Кудренко, О.О. Коваленко, І.П. Хоменко, В.О. Жаховський, В.Г.Лівінський, В.Г.Волоха, В.І.Коробка, Л.М.Шугалей, В.В.Колесник, Ю.В.Інкелевич, В.В.Кулик, М.В.Воловик, Г.М. Сіроштан // “Щорічна доповідь про стан здоров'я населення, санітарно-епідемічну ситуацію та результати діяльності системи охорони здоров'я України. 2017 рік” / МОЗ України, ДУ “УІСД МОЗ України”. - Київ, 2018. - 458 с. 
12. Офіційна позиція колективу медиків-науковців Національної академії медичних наук України з приводу неправдивої інформації, розповсюдженої керівництвом МоЗ України, про діяльність Академії // [Електронний ресурс] - Режим доступу: http://amnu.gov.ua/official-position-of-nams-of-ukraine/ Заголовок з екрана. Знято 0405.2020 р.

13. Про взаємодію медичних служб Збройних Сил та інших військових формувань із державною системою охорони здоров'я і про створення загальнодержавної системи екстремальної медицини / Постанова Кабінету Міністрів України від 16 жовтня 1995 року № 819.

14. Про додаткові заходи щодо забезпечення функціонування закладів охорони здоров'я в умовах особливого періоду та подолання наслідків надзвичайної ситуації державного рівня соціального та воєнного характеру // Наказ Міністерства охорони здоров’я України від 18 лютого 2015 року № 75.

15. Деякі питання медичного забезпечення військовослужбовців, осіб рядового і начальницького складу та поліцейських, які беруть участь в антитерористичній операції та здійсненні заходів із забезпечення національної безпеки і оборони, відсічі і стримування збройної агресії Російської Федерації у Донецькій та Луганській областях // Розпорядження Кабінету Міністрів України від 24 травня 2017 року № 352-р.

16. Про визначення механізму надання вторинної (спеціалізованої) і третинної (високоспеціалізованої) медичної допомоги військовослужбовцям, які беруть участь в антитерористичній операції та здійсненні заходів із забезпечення національної безпеки і оборони, відсічі і стримування збройної агресії Російської Федерації та/або в умовах запровадження воєнного чи надзвичайного стану // Наказ Міністерства оборони України та Міністерства охорони здоров'я України від 7.02.2018 року № 49/180 (зареєстрований у Міністерстві юстиції України 28.02.2018 року за № 252/31704 (зі змінами).

17. Жаховський В.О., Лівінський В.Г. Єдиний медичний простір та військова медицина // Монографія. ISBN 978-617-7638-00-0 / Київ: «Видавництво Людмила». - 2018. - 336 с.

18. Методичні рекомендації з організації роботи цивільних закладів охорони здоров'я щодо надання вторинної (спеціалізованої) та третинної (високоспеціалізованої) медичної допомоги військовослужбовцям Збройних Сил України та інших військових формувань // В.О. Жаховський, В.Г. Лівінський / Київ, видавництво “Людмила”, 2019. - 137 с.

\section{Referenses}

1. On approval of the Doctrine of medical support of the Armed Forces of Ukraine. Order of the General Staff of the Armed Forces of Ukraine № 445 of 20.12.2017.

2. Bundeswehr Health Service.Information Review № 4 (38). Kyiv. 2009. 54 p.

3. Badyuk M.I., Rudynsky O.V. and others. (2014) Organization of medical support of the armed forces of European states: textbook. way. from a foreign course. honey. terminology. K.: SPD Chalchynska NV. 104 p.

4. Golota A.S. (2014) "Medical Service of the Norwegian Armed Forces" Journal "Military Medical Journal". № 9. P. 68-73.

5. Golota A.S. (2016) "Medical Service of the Lithuanian Armed Forces" Journal "Military Medical Journal". № 1. P. 49-53.

6. Aleinikov S.V. (2015) "Medical Service of the National Armed Forces of Latvia". Journal "Military Medical Journal". № 8. P. 58-62.

7. Anisimov A.S. (2015). “Estonian Defense Medical Service”. Military Medical Journal. № 6. P. 61-64.

8. An Israeli doctor told about the experience of Israeli military medicine - [Electronic resource], - Access

mode:

http://galinfo.com.ua/news/izrailskyy_likar_rozpoviv_pro_dosvid_viyskovoi_medytsyny_izrailyu_189706.html. Title from the screen. Taken on April 1, 2015

9. Melnik P.S. Kudrenko M.V., Kozinchuk H.A., Verba A.V., Zhakhovsky V.O., Livinsky V.G., Galatsan O.V., Filipishin V.P., Drobotun O.V., Budyak N.Yu., Klimenko M.P., Klymenko V.I. (2016). Characteristics of medical support of anti-terrorist operation. "Annual report on the state of health of the population, sanitary and epidemiological situation and the results of the health care system of Ukraine. 2015" Ed. Shafransky V.V.; Ministry of Health of Ukraine, State Institution "UISD of the Ministry of Health of Ukraine”. Kyiv, 452 p.

10. Melnik P.S. Kudrenko M.V., Slabkiy G.O., Kovalenko O.O., Verba A.V., Zhakhovsky V.O., Livinsky V.G., Korobka V.I., Shugaley L.M., VolohaV.G., Siroshtan G.M., Klymenko V.I., Kolesnik V.V., Kulik V.V., Inkelevych Yu.V. (2017) Characteristics of medical support in the area of the anti-terrorist operation. "Annual report on the state of health of the population, sanitary and epidemiological situation and the results of the health care system of Ukraine. 2016" / Ministry of Health of Ukraine, State Institution“ UISD of the Ministry of Health of Ukraine ”. Kyiv, P. 384-432.

11. Melnik P.S., Kudrenko M.V., Kovalenko O.O., Khomenko I.P., Zhakhovsky V.O., Livinsky V.G., Volokha V.G., Korobka V.I., Shugaley L.M., Kolesnyk V.V., InkelevichY.V., Kulik V.V., Volovyk M.V., Siroshtan G.M. (2018). 
Characteristics of medical support in the area of the anti-terrorist operation. "Annual report on the state of health of the population, sanitary and epidemiological situation and the results of the health care system of Ukraine. 2017 "/ Ministry of Health of Ukraine, State Institution“ UISD of the Ministry of Health of Ukraine ". Kyiv, 458 p.

12. Official position of the team of physicians-scientists of the National Academy of Medical Sciences of Ukraine on false information disseminated by the Ministry of Health of Ukraine about the activities of the Academy // [Electronic resource] - Access mode: http://amnu.gov.ua/official-position- of-nams-of-ukraine / Title from the screen. Taken 04.05.2020

13. On the interaction of medical services of the Armed Forces and other military formations with the state health care system and the creation of a nationwide system of extreme medicine. Resolution of the Cabinet of Ministers of Ukraine of October 16, 1995 № 819.

14. On additional measures to ensure the functioning of health care facilities in a special period and overcoming the consequences of an emergency situation of the state level of social and military nature. Order of the Ministry of Health of Ukraine of February 18, 2015 № 75.

15. Some issues of medical care for servicemen, privates and officers and police officers involved in the anti-terrorist operation and the implementation of measures to ensure national security and defense, repel and deter armed aggression of the Russian Federation in Donetsk and Luhansk regions. Order of the Cabinet of Ministers of Ukraine dated May 24, 2017 № 352-r.

16. On determining the mechanism of providing secondary (specialized) and tertiary (highly specialized) medical care to servicemen participating in the anti-terrorist operation and implementation of measures to ensure national security and defense, repel and deter armed aggression of the Russian Federation and / or in the context of military or state of emergency . Order of the Ministry of Defense of Ukraine and the Ministry of Health of Ukraine dated February 7, 2018 № 49/180 (registered with the Ministry of Justice of Ukraine on February 28, 2018 under № 252/31704 (as amended).

17. Zhakhovsky V.O., Livinsky V.G. (2018).Unified medical space and military medicine: Monograph. Kyiv: Lyudmila Publishing House. 336 p. ISBN 978-617-7638-00-0.

18. Zhakhovsky V.O., Livinsky V.G. (2019). Methodical recommendations on the organization of work of civilian health care institutions on the provision of secondary (specialized) and tertiary (highly specialized) medical care to servicemen of the Armed Forces of Ukraine and other military formations. Kyiv, Lyudmila Publishing House, 137 p.

\section{РАБОТА ГРАЖДАНСКИХ УЧРЕЖДЕНИЙ ЗДРАВООХРАНЕНИЯ ПО ОКАЗАНИЮ МЕДИЦИНСКОЙ ПОМОЩИ ВОЕННОСЛУЖАЩИМ ВО ВРЕМЯ АТО/ООС, А ТАКЖЕ ДЕМОБИЛИЗОВАННЫМ УЧАСТНИКАМ АТО И ВНУТРЕННЕ ПЕРЕМЕЩЕННЫМ С ВРЕМЕННО ОККУПИРОВАННЫХ ТЕРРИТОРИЙ ЛИЦАМ}

\section{В.Г. Ливинский}

Украинская военно-медицинская академия, г. Киев

Цель работы - анализ и обобщение опыта работы гражданских учреждений здравоохранения по оказанию медицинской помощи раненым, травмированным и больным военнослужащим во время антитеррористической операции и операции Объединенных сил (АТО/OОС), а также демобилизованным участникам АТО и внутренне перемещенным лищам из временно оккупированных территорий АР Крым, Донецкой и Луганской областей.

Материалы и методы. Использованы нормативно-правовые акты по вопросам обороны государства и здравоохранения, руководящие документы, информационные издания по вопросам охраны здоровья населения и медицинского обеспечения Вооруженных Сил (ВС) Украины. Методы исследования: исторический, библиографический, системного подхода, статистический, аналитический, обобщения.

Результаты. $B$ статье рассмотрены исторический и зарубежный опыт использования гражданских учреждений здравоохранения для оказания медищинской помощи военнослужащим во время войн и вооруженных конфликтов, исследованы нормативно-правовые основы привлечения их к системе лечебно-эвакуационных мероприятий медицинского обеспечения ВС Украины. Проанализирована работа учреждений здравоохранения коммунальной собственности и клинических учреждений Национальной академии медицинских наук Украины по оказанию медицинской помощи раненым, травмированным и больным военнослужащим, демобилизованным участникам АТО и внутренне перемещенным с временно оккупированных территорий лицам, а также исследованы факторы, которые влияли на их работу.

Выводы. В районах проведения АТО/OОС на основе единого медицинского пространства сформировалась территориальная система оказания медицинской помощи раненым, травмированным и больным военнослужащим, которая функционально объединила медицинские подразделения воинских 
частей $и$ соединений, военно-медицинские учреждения, а также гражданские учреждения здравоохранения. По опыту медицинского обеспечения войск во время АТО/ООС разработан механизм и порядок привлечения системы гражданской здравоохранения к оказанию медицинской помощи военнослужащим во время войн и вооруженных конфликтов.

Ключевые слова: здравоохранение, медицинская помощь, медицинское обеспечение.

\title{
THE WORK OF CIVILIAN HEALTH FACILITIES TO PROVIDE MEDICAL ASSISTANCE TO SERVICEMEN DURING THE ATO/JFO, AS WELL AS TO THE DEMOBILIZED PARTICIPANTS IN THE ATO AND INTERNALLY DISPLACED PERSONS FROM THE TEMPORARILY OCCUPIED TERRITORIES
}

\author{
V. Livinskyi \\ Ukrainian military medical academy, Kyiv
}

The purpose of the work is to analyze and summarize the experience of civilian health care facilities in providing medical care to wounded, injured and sick servicemen during the anti-terrorist operation and the Joint Forces (ATO/JFO) operation, as well as demobilized ATO participants and internally displaced persons with temporarily occupied territories of the Autonomous Republic of Crimea, Donetsk and Luhansk regions.

Materials and methods. Regulations on state defense and health care, guiding documents, information and reference publications on public health and medical care of the Armed Forces (AF) of Ukraine were used. Research methods: historical, bibliographic, systems approach, statistical, analytical, generalization.

Results. The article considers the historical and foreign experience of using civilian health care facilities to provide medical care to servicemen during wars and armed conflicts, examines the legal framework for their involvement in the system of medical and evacuation measures of medical support of the Armed Forces of Ukraine. The work of public health care institutions and clinical institutions of the National Academy of Medical Sciences of Ukraine to provide medical care to wounded, injured and sick servicemen, demobilized members of the ATO and internally displaced persons from the temporarily occupied territories, as well as factors influencing their work.

Conclusions. In the areas of ATO/JFO, on the basis of a single medical space, a territorial system of medical care for the wounded, injured and sick military personnel was formed, which functionally united the medical units of military units and formations, military medical institutions, as well as civilian healthcare institutions. Based on the experience of medical support of troops during the ATO/JFO, the mechanism and procedure for involving the civilian health care system in the provision of medical care to servicemen during wars and armed conflicts have been worked out.

Key words: healthcare, medical care, medical support.

\section{Відомості про автора:}

Лівінський В.Г., кандидат медичних наук, Науково-дослідний інститут проблем військової медицини Української військово-медичної академії, провідний науковий співробітник науково-дослідного відділу медичної стандартизації та метрологічного забезпечення, м.Київ.

\section{Сведения об авторах:}

Ливинский В.Г., кандидат медицинских наук, Научно-исследовательский институт проблем военной медицины Украинской военно-медицинской академии, ведущий научный сотрудник научноисследовательского отдела медицинской стандартизации и метрологического обеспечения, г. Киев.

Information about authors:

Livinskyi V.G., MD PhD, Research Institute of Military Medicine of the Ukrainian Military Medical Academy, leading researcher of the research department of medical standardization and metrological support, Kyiv,_ORCID ID 0000-0002-1102-1128, Email: v.livinskiy@gmail.com. 